\title{
REVIEWS
}

Reviews of books, reports, papers and other publications should be sent to J. Walter Giles, Book Review Co-ordinator, Department of Lands and Forests, Pembroke, ont. Please mention that you saw the review in the Forestry Chronicle when purchasing books from publishers.

Animal Control in Field, Farm and Forest

By W. Robert Eadie. Macmillan, N.Y., viii-257 pp. 1954. \$3.75.

Foresters will find less about the forest in this book than about field and farm. Nevertheless, this volume is recommended to the forester with a problem involving protection from injurious mammals. (The book deals with only one group of animals-the Mammalia. It would be useful if printers would give titles to their non-fiction which were at least not misleading.)

Eadie has produced a book long needed. The mammal that is giving you trouble is considered in this book if you live in North America. Ideas presented are applicable elsewhere, of course. The plan of the book is straightforward. Each species or group of similar species is. described; life history is noted briefly; economic status is discussed thoroughly; control measures are treated fully; and natural enemies are noted.

A tremendous volume of literature has been condensed into one book. It is essentially a compilation into one volume of our knowledge about how to deal with troublesome North American mammals. In this Eadie succeeded admirably. Our knowledge, however, seems to fall down badly on some points. If one left out all references to shooting, trapping, poisoning, fencing, gasing and making buildings mammal-proof, there would be little left to say. In short, repellants have had little success to date, and the use of "natural and ecological principles" to keep mammals in line is not much more advanced. While there is a bewildering volume of ecological data on the mammals of America, students have obviously been more concerned with facts per se than with facts of use to man. A noteworthy exception in this regard concerns the meadow mice. Excellent directions are given for this species on how to keep down numbers by the removal of ground cover. These are quite sound for application in forest plantations.

There are several things I wanted to find in this book, but I was disappointed. Troublesome bears in parks, we are told, can be shot, or live trapped and trucked into remote areas. As a camper in parks, however, I want to know how to encourage a bear to leave my picnic table when the animal has no fear of me. This sounds simple enough, but I can speak from experience in saying it is not. Again, I hoped to find an up-to-date account of Peromyscus control in direct seeding operations, but found only how to use time-honored poisons like strychnine. And for the same animal, I found no description of a trap which I can leave in my cabin and be assured that it will continue to catch mice until my return next month. Apparently no one has published descriptions of several such traps I have seen in backwoods Canada. 
Throughout his book, Eadie emphasises that control is justified only when needed. This seems obvious enough until one looks into our history of controls on wolves, coyotes, cougars and similar large predators.

I feel that the author omitted one matter of importance. For each species he records litter size, litter frequency, etc., all of which is useful, and none of which looks very impressive to the casual reader. Eadie might well have stressed in his introduction the remarkable ability of animals to multiply, not arithmetically, but like compound interest. Keeping down the numbers of most mammals is a continuing task, and involves opposing a considerable reproductive force. I am reminded of the words of a biologist watching poisoning operations in an area to be seeded-"It's something like bailing a hole in a lake."

This will be our standard book on the control of mammals for many years. Foresters can use it in many ways.

R. Y. EDWARDs.

\section{Geography of the Northlands}

Edited By: George H. T. Kimble and Dorothy Good, American Geographical Society and John Wiley \& Sons, New York. 1955. $\$ 10.50$.

In recent years the arctic and sub-arctic regions of the world have been the subject of much public interest, both in this country and abroad. This interest has been largely sparked by the strategic military location of the area, lying as it does on the shortest air routes between the two principal world powers, the United States and Russia.

During the past few years, too, there have been sensational mineral discoveries in northern Canada which have focused much attention on the area. Notable among these have been the development of iron mines in Labrador, uranium mines in northern Saskatchewan, gold mines at Yellowknife and asbestos mines in northern British Columbia. Such discoveries have greatly encouraged prospectors to venture further afield in search of more of these rich deposits.

The popular press of both the United States and Canada has taken note of the development in the North with many news items and feature articles. In the main these constitute good sober reporting but are usually the result of a flying visit to the region which does not give the reporter time to obtain more than a superficial picture of conditions there, however observant he may be. It is thus an opportune time for the appearance of a work such as Geography of the Northlands which attempts a factual appreciation of the north in all its aspects.

The book is circumpolar in scope, covering the arctic and sub-artic portions of Europe, Asia, North America and the islands of the North Atlantic. The definitions of arctic and sub-arctic are on an isothermal rather than a latitudinal basis. The entire area under review is first treated as a unit and its physiography, climate, terrestrial and marine ecology, peoples, resources and political and strategic aspects are separately discussed. The area is then broken down into regions, each of which is discussed under similar headings. This 
system leads to less repetition than might be supposed but, as the sections are by different authors, some slight conflicts do appear.

Where the matters discussed lie within the reviewer's experience, the authors appear to have their facts reasonably straight, although in some cases they are already obsolete. This is true of the description of transportation facilities in the Yukon where river transport has now been almost completely superseded by road transport as new highways have been completed to all important centres. Mention of asbestos prospects in Alaska, while omitting any reference to the rich producing Cassiar asbestos mine in northern B.C., can only by ascribed to dependence on out-of-date information sources.

Such lapses can be excused, however, in a work of such over-all excellence. The inclusion of the European and Asiatic north in the same volume with the North American is particularly to be commended. This arrangement points up the remarkable homogeneity of these widely scattered areas and demonstrates that techniques of adaptation to the harsh environment learned in one sector of the arctic can be successfully applied elsewhere. Due to greater population pressures to the south and, in the case of Russia, more forceful methods, the European and Asiatic northland is more heavily populated and fully developed than our own. Many of the problems they are facing now will be ours in the near future, and a close study of their experience should be rewarding. Russia is the country which is likely to have the largest quantity of pertinent experience, and while reliable data may be difficult to secure, any which does become available should receive careful study.

This book does not lie within the realm of light literature. It describes itself as a textbook and that is percisely what it is. It is not, however, a difficult book to read although a few more definitions and perhaps even a glossary would have been appreciated. The photographs, while not very profuse, are of universally excellent quality and interest. The maps, on the other hand, give away nothing; information has to be extracted from them. A large percentage of Canadian foresters live in or are concerned with the areas described in this book and it should prove of real value to those genuinely interested in the larger aspects of their environment. It is a good reference work for all those who maintain an interest in northern development and will assist greatly in giving background and perspective to current news of developments there.

G. M. WILSON.

\section{Management Records, The Maintenance of Histories of Forest Management Units of the British Commonwealth}

By N.V. Brasnett, 1954. Institute Paper No. 30, Imperial Forestry Institute, University of Oxford, England, $82 \mathrm{pp} .6 /$.

Mr. Brasnett was requested by the sixth British Commonwealth Forestry Conference to compile this collation of information supplied by Commonwealth agencies. He sent questionnaires to all Departments in the Commonwealth concerning the records and histories maintained for their management units.

Any Canadian Forester interested in devising a record system for the area he manages would find this detailed account useful. Although conditions 
and intensity of management vary greatly throughout the Commonwealth, there is a pattern that emerges from the perusal of the various records outlined in Mr. Brasnett's publication.

He provides some helpful suggestions based on his study of the information supplied him. These may be briefly summarized:

1. Intensity of recording depends on intensity of management. He warns against too ambitious and laborious records where staff shortages may some day result in failure to maintain them.

2. Unit records intergrated with administrative records can form the bases of the latter and save duplication.

3. Working plan prescriptions are not part of historical records, which are statements of fact.

4. Experimental plot data should be kept separate as research records, not included in compartment files.

5. General descriptions of locality should form a permanent section when the records are initiated.

6. Consider carefully headings used and omit any likely not to be permanent.

7. Use good quality loose-leaf sheets in a hard-covered binder where records are to be kept a long time.

Generally different types of records are kept for management in the natural forest and for the establishment of plantations since the information likely to be recorded differs considerably.

J. Walter Giles.

The Flood Control Controversy: Big Dams, Little Dams and Land Management.

By Luna B. Leopold and Thomas Maddock Jr. Ronald Press. N.Y. xiï278. 1954. $\$ 5.00$.

The controversy referred to here is a famous one in the United States. In one corner are those who advocate, in conjunction with good land management, many small dams upstream to control floods; in the other are those seeking to harness floods behind large dams on the main downstream stems of rivers. The book is written by authors highly qualified to analyse both the controversy and the whole question of flood control. The result is most informative.

The public, which I suppose includes foresters, is largely misinformed about floods in general and their control in particular. The misconceptions appear to have been fostered by groups, both lay and professional, with axes to grind. Its an old story in a new setting. The land manager, in his zeal to promote a better agriculture, has often made unjustified claims for the flood control benefits of his measures. On the other hand, engineers trained to build big dams are quite happy to let them appear as the only efficient solution to the flood problem. Meanwhile, John Public pays the bill in this era of narrow experts who have not faced with honesty the limitations of their callings.

Unless you are unusually well informed about floods and their control, there are facts in this book that will change your thinking. Floods are a natural attribute of rivers, having created the agriculturally rich flood plains that attract 
man and his works. There is no such thing as absolute flood control. There can always be the bigger run-off which will swamp control measures and flush out the valley below. Dams can lead to an attitude of false security, encourage an intensified use of flood plains by man, and so cause greater economic losses when they fail.

The controversy has ben argued in blacks and whites, but as usual the shades are really grey. Upstream and downstream measures both have their role to play. I am not sure that the authors intended it, but I gained the impression that upstream measures should be intensified, while there is some justification for easing up on the construction of big dams downstream, at the same time intensifying measures which control the use of flood plains so that floods will find little to damage.

Foresters will find little here that deals with run-off from forest lands. The controversy discussed is set in an agricultural and industrial area. But there is much of value here, especially for foresters working in southern Ontario.

R. Y. EDWARDS.

\section{Development of a Balsam Fir and White Spruce Forest in Northwestern New Brunswick}

By A. B. Vincent. (Forest Research Note, Technical Note No. 6, Forestry Branch, Dept. of Northern Affairs and National Resources) Queen's Printer, Ottawa, 27 pp., illus., 1955.

Some readers might charge that the title of this pamphlet-style publication is misleading. Because the title is already lengthy, little harm would be done by the addition of three more words. "Five Years of Development in a Balsam Fir and White Spruce Forest in Northwestern New Brunswick" might convey a more-accurate idea of the content. Whatever the title, this is a detailed yet concise story of five years of forest change on the 3285 forested acres of Green River Research Block One which remained undisturbed between 1945 and 1950.

The note consists of fifteen pages of text, including short tabulations and illustrative graphs but excluding two good maps, four excellent photographs, and four Appendix tables, all of which are separate from the text. In five text pages the author introduces and locates his subject, outlines both field and office methods, and describes briefly the physiography, climate, tree species, cover types and forest history of the area. On the other ten pages he presents and discusses the results obtained from the study.

The "Results and Discussion" section is subdivided into seven major parts, one describing each of the six forest types recognized and the last comparing the results for all. For each type the numbers of living trees, the merchantable softwood volumes, and the numbers of reproduction-size stems are tabulated on a per-acre basis for 1945 and for 1950. The first of these is illustrated by bar graphs. Noteworthy changes in diameter increment are mentioned briefly. Gross periodic annual increment is broken down into mortality, windfall, and net increment components-all in cubic feet per acre. The subsection is concluded with a short paragraph on probable future development and, in the case of types containing mature trees, a cutting treatment 
recommendation. All of this information is presented in scarcely more words than are required to outline the content.

A large volume of numerical data forms the basis for Mr. Vincent's Technical Note, although he never troubles the reader with that fact. The publication might well serve as a model for the condensation and presentation of such information. The words which explain and complement the numerical story are clear and simple. The whole is a concise, readable documentation of five years of forest change on a specific block of B2 Boreal Forest.

A. L. VanSlyKe.

\section{CURRENT PUBLICATIONS}

\section{MANAGEMENT}

Baxter, Dow V. and Tom Grow. Unusual decay in young oak plantations following early rodent injury. Michigan Forestry Note No. 12, Department of Forestry, University of Michigan, Ann Arbor. June 1955. 2 p.p.

Borzuchowski, R. Partial time study of a second-growth Hemlock thinning. Research note 30, B.C. Forest Service, Victoria, B.C. 19.55. 13 p.p.

Beckwith, L. C. and H. G. Ewan. The Forest Insect Situation, Lake States 1955. Sta. Paper 35, Lake States F.E.S., St. Paul, Minn. 1956. 15 p.p.

Church, T. W. Stocking and yield of Virginia Pine stands in Prince George's County, Maryland. Research note 44, Northeastern Forest Experiment Station, Upper Darby, Pa. 1955. 4 p.p.

Cook, D. B., and L. S. Hamilton. More about chemi-peeling. Reprint from Northeastern Logger-4, 2. 1955. 4 p.p.

Cramer, O. P. 1955 forest fire weather in western Oregon and Washington. Res. Note 123-Northwest Forest and Range Expt. Sta., Portland, Oregon. 1955. 7 p.p.

Cunningham, R. N. Forest Ownership Stabilizing in Lake States. Tech. Note 448, Lake States F.E.S., St. Paul, Minn. 1956. 2 p.p.

Dyer, H. L., R. T. Thaxter and H. E. Young. Pulpwood cull void tables tech. note 38, University of Maine, Forestry Department, Orono, Maine. 1955. 6 p.p.

Graham, S. A. and R. P. Harrison. Site identification for bigtooth aspen sucker stands, Michigan Forestry No. 10, Department of Forestry, University of Michigan, Ann Arbor. 1955. 4 p.p.

Godman, R. M. Progress of top dying in Yellow Birch-Upper Michigan 1954-55. Tech. Note 444, Lake States. F.E.S., St. Paul, Minn. 1956. 2 p.p.

Guilkey, P. C. Short bolts offer better hardwood utilization. Tech. Note 446, Lake States F.E.S., St. Paul, Minn. 1956. 2 p.p.

Guilkey, P. C. and R. W. Blair. Costs of chemical debarking of Oak in lower Michigan. Tech. Note 445, Lake States F.E.S., St. Paul, Minn. 1956. 2 p.m.

Hampf, F. F. Relationship of stump diameter to D.b.h. for yellow poplar in the Northeast. For. Res. Note 55, Northeastern Forest Expt. Sta., Upper Darby, Pa. 1955. 4 p.p. 
Johnson, Floyd A. Estimating past diameters of Douglas-fir trees. Research Note 112, Pacific Northwest, F.R.E.S., Portland, Oregon. 19.55. 3 p.p.

Ker, J. W. and J. H. G. Smith. Advantages of the parabolic expression of height-diameter relationships. Res. Paper 10, Faculty of Forestry, U.B.C., Vancouver, 1955.

MacAndrews, F. D. Average height weighted by volume in air photo interpretation. Tech. Note 17, For. Branch, Ottawa. 1955. 11 p.p.

MacLean, D. W. and G. H. D. Bedell. Northern Clay Belt growth and yield survey. Tech. Note 20, Forest Research Division, Forestry Branch, Ottawa. 1955. 31 p.p.

McCormack, J. F. An allowance for bark increment in computing tree diameter growth for Southeastern species. Sta. Pap. 60. Southeastern For. Expt. Sta., Ashville, N.C. 1955.6 p.p.

Mawson, J. C. and H. E. Young. Topwood volume tables second growth hem'ock, old growth hemlock and red spruce. Tech. Note 39, University of Maine, Forestry Department, Orono, Main. 1956. 4 p.p.

Mullin, R. E., L. M. Morrison and T. T. Schweitzer. Inventory of nursery stock. Research Report 33, Division of Research, Ontario Department of Lands and Forests, Toronto. 1955. 64 p.p.

Senda Masaji and Kanjiro Maezawa. "On the measurement of stands basal area by the Biterlich method". Tokyo University Forests, Miscellaneous Information Report 10, 1955, translated by Kanjiro Maezawa, University of British Columbia. 1955. 11 p.p.

Steele, R. W. and N. P. Wortbington. Increment and mortality in a virgin Douglas-fir forest. Research Note 110, Pacific Northwest F.R.E.S., Portland, Oregon. 1955. 5 p.p.

Stoeckeler, J. H. and Carl Arbogast Jr. Forest management lessons from 1949 windstorm in Northern Wisconsin and Upper Michigan. Station Paper 34, Lake States, F.E.S. 1955. 11 p.p.

Trousdell, K. B. Loblolly pine seed tree mortality. Sta, Pap. 61 Southeastern For. Expt. Sta., Asheville, N. C. 1955. 11 p.p.

Wear, J. F, and W. J. Buckhorn. Organization and conduct of forest insect aerial surveys in Oregon and Washington. Pacific Northwest F.R.E.S., Portland, Oregon. 1955. 41 p.p.

Williams, D. E. Fire hazard resulting from jack pine slash. Tech. Note 22, Forest Research Division, Forestry Branch, Ottawa. 1955. 17 p.p.

Young, H. E. Local pulpwood volume tables. Tech. Note 37. Forest Department, University of Miane, Orono. 19.55. 5 p.p.

\section{SILVICULTURE}

Anderson, R. L., D. D. Skilling and E. D. Clifford. Nursery root disease control by soil fumigation. Tech. Note 449 , Lake States F.E.S., St. Paul, Minn. 1956. 1 p.

Crossley, D. I. The production and dispersal of lodgepole pine seed. Tech. Note No. 25, Forestry Branch, Ottawa. 1955. 12 p.p. 
Crossley, D. I. Mechanical scarification to induce white spruce regeneration in old cut-over Spruce stands. Tech. Note 24, Forest Research Division, Forestry Branch, Ottawa. 1955. 12 p.p.

Graham, S. A. Ecological classification of vegetation types. Michigan Forestry No. 11, Department of Forestry, University of Michigan, Ann Arbor. 1955. 2 p.p.

Isaac, $\mathrm{L}$. A. Tentative guides for the selection of plus trees and superior stands of Douglas-fir. Research Note 112-Pacific Northwest F.R.E.S., Portland, Oregon. 1955. 9 p.p.

Johnson, H. J. The effect of various slash disposal methods on the regeneration of cut-over jack pine stands. Tech. Note 23, Forest Research Division, Forestry Branch, Ottawa. 1955. 12 p.p.

Mergen, F., H. Rossoll, K. B. Pomeroy. How to control the pollination of slash and longleaf pine. Station Paper No. 58, Southeastern F.E.S., Asheville, N.C. 1955.14 p.p.

Merz, R. W. Yellow-Poplar responses to replanting ground treatment. Tech. paper 150, Central States. F.E.S., Columbus, Ohio. 1955. 18 p.p.

Mows, E. H. The vegetation of Alberta. The Botanical Review, volume 21 No. 9, Nov. 1955. Box 749, Lancaster, Pa. 74 p.p.

Redmond, D. R. Warmer soils kill yellow birch. Contribution 178, Forest Biology Division, Science Service, Ottawa. 1955. 2 p.p.

Rudolph, P. O. 1955 forest trees seed crop generally fair in the Lake States. Tech. Note 447, Lake States F.E.S., St. Paul, Minn. 2 p.p.

Schmidt, R. L. Some aspects of western red cedar regeneration in the coastal forests of British Columbia. Research Note 29, B.C. Forest Service, Victoria, B.C. 1955.10 p.p.

Siren, G. The development of spruce forest on raw humus sites in Northern Finland and its ecology. Reprint from Acta Forestalia Fennica, 62. Helsinki. 1955. 408 p.p.

Stiell, W. M. The Petawawa Plantations. Tech. Note 21, Forest Research Division, Forestry Branch, Ottawa. 1955. 46 p.p.

Stoate, T. N. Some aspects of forest establishment and growth. U.B.C., Vancouver. 1955. 13 p.p.

Worthington, N. P. A comparison of conifers planted on hemlock experimental forest. Research Note 111, Pacific Northwest F.R.E.S., Portland, Oregon. 1955. 5 p.p.

\section{UTTLIZATION}

Anon: Procedures for measuring the mold resistance of protein glues. No. 1344, Forest Products Laboratory, Madison, Wisc. 1955. 8 p.p.

Boller, K. H. Effect of long-term loading on glass-fiber-reinforced plastic laminates. No. 2039, Forest Products Laboratory, Madison, Wisc. 1955. 42 p.p. 
Baird, P. K., J. S. Martin, and D. J. Fahey. Bond and magazine papers and milk-carton paperboard from old-growth Douglas-fir and red alder pulps. No. 2042, Forest Products Lab., Madison, Wisc. 1955. 14 p.p.

Erickson, E. C. O. and C. B. Norris. Tensile properties of glass-fabric laminates with laminations oriented in any way. No. 1853, Forest Products Lab., Madison, Wisc. 1955. 50 p.p.

Fraes, A. D., and F. Werren. Supplement to directional properties of glass fabric-base plastic laminate panels of sizes that do not buckle. No. 1803 B. Forest Products Lab., Madison, Wisc. 1955. 48 p.p.

Ladell, J. L. High-temperature drying of lumber. Forest Product. Lab., Ottawa. 1955. 5 p.p.

May, R. H. and L. N. Erickson. Wood residue from primary wood-using industries in California. Tech. Pap. No. 13. Cal. Forest and Range Expt. Sta., Berkely, Calif. 1955. 15 p.p.

Northcott, P. L. Bond strength as indicated by wood failure or mechanical test. For. Products Lab., Ottawa. 1955. 6 p.p.

Paul, B. H., A. W. Dohr, and J. T. Drow. Specific gravity, shrinkage and strength of $\tan$ oak. No. 2041, For. Products Lab., Madison, Wisc. 1955. 16 p.p.

Peck, E. C. Moisture content of wood in use. No. 1655 For. Products Lab;, Madison, Wisc. 1955. 10 p.p.

Raville, M. E. Deflection and stresses in an uniformly loaded, simply supported, rectangular sandwich plate. No. 1847, For. Products Lab., Madison, Wisc. 1955. 54 p.p.

Rudnicki, J. M. A scientific approach to the design of wooden containers and the design and use of pallets. Forest Products Lab., Ottawa. 1955. 4 p.p.

Schafer, E. R., J. S. Martin and E. L. Keller. Pulping characteristics of Lake States and Northeastern woods. No. 1675. For. Products Lab., Madison, Wisc. 1955. 26 p.p.

Simmons, Fred C. Adaptability of sash gang saw mills to northeastern conditions. Station Paper 78, Northeastern F.E.S. Upper Darby 10, Pa. 1955. 7 p.p.

Smith, Diana M. Relationship between specific gravity and percentage of summerwood in wide-ringed second-growth Douglas-fir. No. 2045. For. Products Lab., Madison, Wisc. 1955. 20 p.p.

Youngquist, W. G., and E. W. Kuenzi. Supplement to stresses induced in a sandwich panel by load applied at an insert. No. 1845-A, Madison, Wisc. 1955.32 p.p.

TABLE OF CONTENTS

JOURNAL OF FORESTRY

\section{January}

A Site Evaluation Concept-Svend O. Heiberg and Donald P. White Boron Level and Boron Toxicity in Red and White Pine-E. L. Stone and Guy Baird 
Regeneration of Aspen Cutover Areas in Northern Wisconsin-J. H. Stoeckeler and John W. Macon

Forest Service Policies as They Affect the Lumber Industry: A Case Study of the Black Hills-Carl A. Newport

Some Effects of Depth on Planting upon Loblolly Pine in the North Carolina Piedmont-G. K. Slocum and T. E. Maki

Decay Following Thinning of Sprout Oak Clumps-Elmer R. Roth

Damage to Paper Birch by Red Squirrels in Alaska-H. J. Lutz

Pin-Pointing, a Surveying Technique for Foresters-Gordon R. Heath

\section{February}

Two Methods of Thinning Young Lodgepole Pine in the Central Rocky Mountains-R. R. Alexander

Factors Affecting Small-Woodland Management in Nacogdoches County, Texas-A. L. Mignery

An Early Test of Levels of Growing Stock in Appalachian HardwoodsW. G. Wahlenberg

The Spacing Intervals for Supplemental Shelterbelts-N. P. Woodruff

Forest Inventory for Management of State Lands in Minnesota-Richard L. Knox

Effects of Thinning a 55-Year-Old Western White Pine Stand-Marvin W. Foiles

\section{March}

The American Forestry Association's First Eighty Years-Samuel T. Dana

Tax Assessment of Forest Land and Timber Shows Improvement-Ellis T. Williams

Intermediate Yields of Douglas-Fir as Interpreted from British Yield TablesGeorge H. Barnes

Seed Spot Methods of Censusing Forest Rodents-Lloyd Tevis, Jr.

A Cylindrical Screen for Protecting Direct Seedings of Forest Tree SpeciesJ. H. Stoeckeler and H. F. Scholz

A Simplified Method for Estimating Form Class of Loblolly and Shortleaf Pine Stands in Mississippi-Allen F. Horn

Results of Several Methods of Release of Understory Loblolly Pine in Upland Hardwood Stands_-William D. Miller and Oscar C. Tissue 